\title{
Aerial root hydraulic conductivity increases with plant size for the aroid vine Rhodospatha oblongata (Araceae)
}

\author{
Arinawa L. Filartiga ${ }^{1}$, Ricardo C. Vieira ${ }^{2,4}$, and André Mantovani ${ }^{3}$ \\ ${ }^{1}$ Universidade Federal do Rio de Janeiro, Museu Nacional, Rio de Janeiro, RJ, Brasil; ${ }^{2}$ Universidade \\ Federal do Rio de Janeiro, Instituto de Biologia, Departamento de Botânica, Laboratório de Morfologia \\ Vegetal, Bloco A, sala A1 108, CCS, Cidade Universitária, Rio de Janeiro, RJ, Brasil; ${ }^{3}$ Instituto de \\ Pesquisas Jardim Botânico do Rio de Janeiro, Rua Pacheco Leão 915, Jardim Botânico, 22460-030 Rio de \\ Janeiro, Brasil.
}

Corresponding author: André Mantovani, andre@jbrj.gov.br

Date of submission: December $11^{\text {th }} 2017$

Date of publication: May $26^{\text {th }} 2018$

\section{Abstract}

Rhodospatha oblongata (Araceae) is an aroid vine which reaches maturity at tree canopies. The beginning of its ascension towards the canopy occurs when one of the branches reaches the stem of a host, thenceforward reaching eight to ten meters in height. Throughout this ascendant path, $R$. oblongata develops two types of aerial roots: anchor roots, which are shorter and adhere to the host, never reaching the soil, and feeder roots, which are longer and also adhere to the host, but connect the vine to the forest soil. The morphological, anatomical and physiological aspects of both root types are herein compared in relation to the efficiency of axial hydraulic conductivity. It is hypothesized that $i)$ the two root types present distinct xylem hydraulic conductivity and ii) hydraulic conductivity of both roots varies with plant size. Root characterization was based on growing $R$. oblongata individuals divided into five size classes. Thirty specimens with both anchor and feeder roots were analyzed along plant size increase. Both roots gradually increase in number and external diameter as $R$. oblongata vertically ascends to reach plant canopies. The stele of both roots increases in diameter, as well as their respective xylem vessels that become larger. The increase in these morphological and anatomical parameters has a positive influence on xylem hydraulic conductivity, which also increases along the ascendance of $\boldsymbol{R}$. oblongata. Comparative measurements show that anchor roots, in general, present smaller morphological and anatomical structures and lower hydraulic conductivity in comparison to feeder roots. Xylem diameter distribution is unimodal for anchor roots, but bimodal for feeder roots. While all feeder roots present a great concentration of vessels around $60 \mu \mathrm{m}$ in diameter, the second peak occurs at xylem diameter values that increase with plant size. These modifications optimize root water transport, while the vegetative body of $R$. oblongata increases in size, connecting its leaves at canopies to the soil water with elevated hydraulic efficiency.

\section{Introduction}

Aroid vines that begin their life cycle as terrestrial plants and later ascend up to the canopy may undergo profound external morphological modifications of the vegetative body, a growth type classified as allomorphic by Ray (1990). As they grow toward the canopy, they gradually develop shorter and thicker internodes that support larger leaves. Ray (1992) suggested that leaf area increase on allomorphic aroid vines would endow them with higher lightharvesting capacity. This hypothesis was recently reinforced by results based on chlorophyll fluorescence analysis where the larger leaves of the allomorphic aroid vine Epipremnum aureum L. presented higher electron transport rates (ETR) than smaller ones, as obtained at higher photon flux densities (Mantovani et al., 2017). In fact, larger leaves of aroid vines are commonly developed under the higher illuminated conditions found at canopy, but not near the forest floor (Mantovani, 1999b).

Low water supply may limit light-harvesting capacity of leaves, decreasing photosynthesis (McCulloh and Sperry, 2005). In this sense, the hydraulic conductivity of aroid vines should improve along their allomorphic growth in order to better supply water to the larger leaves. Besides the increase in shoot and leaf size, water acquisition and transport systems of aroid vines also change in size along their allomorphic growth (Olson et al., 2014; Rosell et al., 
2017). Two aerial root types are developed during the ascendant phase: anchor roots that attach the vine to the host trunk and feeder roots that descend and establish a connection with the soil (Croat, 1988). Both types present size increase in external and stele diameter, as well as xylem vessel diameters, along plant growth, potentially improving hydraulic conductivity to larger leaves.

Only two studies have evaluated the hydraulic conductivity of aerial roots of allomorphic aroid vines. LopezPortillo et al. (2000) described hydraulic conductivity of aerial feeder roots in Monstera acuminata C. Koch., as positively related to their increasing axis, stele and xylem diameters. However, no data were available for anchor roots since their size in this species is much reduced. When Rhodospatha oblongata ascends through the canopy, Filartiga et al. (2014) described that both anchor and feeder roots become longer, wider and more numerous, presenting a wider stele composed of large xylem vessels. This increase of xylem vessel diameter was reported to positively influence plant hydraulic conductivity. The flow rate of water along a xylem vessel is proportional to the fourth power of its radius (Zimmermann, 1983). However, even though wide vessels provide greater hydraulic conductivity to plants, they also potentially decrease their safety against embolism (Zimmermann and Potter, 1982; Gartner et al., 1990; Carlquist, 2012). On the same stele transversal section obtained from any aroid vine root, distinct xylem vessel diameters varying from small to large can be found.

None of the authors above has evaluated how the proportional contribution of small and large vessels, i.e., frequency distribution of xylem vessel diameter, changes along root sizes and root types in aroid vines. Considering that a higher light foraging capacity must be supported by higher hydraulic conductivity in order to improve photosynthesis, we hypothesize that more large-sized, than small-sized, vessels are produced, as long as the aerial roots of allomorphic aroid vines increase in diameter. We also believe that this relative contribution of smaller versus larger vessels will vary with root type, considering that anchor roots primarily provide adherence, while feeder roots primarily provide water and nutrient transport. These hypotheses are tested herein by determining the maximum hydraulic conductivity $\left(\mathrm{Kh}_{\max }\right)$ and frequency distribution of xylem diameters from both aerial anchor and feeder roots of $R$. oblongata along increasing plant and root sizes. Such evaluation may also demonstrate a possible trend toward functional construction of the root stele facing in a manner that would provide for safety with smaller vessels in contrast to conductivity with larger vessels, as long as aroid vines increase in size.

\section{Materials and Methods}

\section{Study site and plant species}

The study was performed in an Atlantic Forest area at Reserva Botânica das Águas Claras $\left(22^{\circ} 30^{\prime} \mathrm{S} ; 4^{\circ}\right.$ $30^{\prime} \mathrm{W}$ ), which is located in the Silva Jardim municipality, State of Rio de Janeiro, Brazil (for climate and vegetation data, see Mantovani, 1999b).

Rhodospatha oblongata begins its life cycle as a terrestrial plant with small leaves and a superficial root system. When some of its branches reach the trunk of a host, the vine begins to grow vertically up to 8-10 m in height (Figure 1). Along this ascent, stem diameter and leaf area increase, along with the simultaneous appearance of two types of aerial roots, anchor and feeder (Figure 1), both of which increase in number and diameter with increasing plant size (Filartiga et al., 2014).

\section{Root morphology, anatomy and physiology}

The influence of root size on the respective hydraulic conductivity of these root types was evaluated for 30 anchor roots and 30 feeder roots. Of these specimens, six samples ( 01 anchor and 01 feeder root per individual plant; 06 plants per size class) each were obtained from plants with different class sizes, according to Filartiga et al. (2014): class I) plants with terrestrial habits (not analyzed owing to the absence of aerial roots); class II) plants with $0-1 \mathrm{~m}$ in height; III) plants with 1-2 $\mathrm{m}$ in height; class IV) plants with 2-3 $\mathrm{m}$ in height; class V) plants with 3-5 $\mathrm{m}$ in height; class VI) plants with 5-7 $\mathrm{m}$ in height. Each root was characterized by its external and stele diameters, total sum of xylem vessel diameters, and maximum axial hydraulic conductivity $\left(\mathrm{Kh}_{\max }\right)$. The hydraulic conductivity values were related to the anatomical parameters of external diameter, stele diameter (stele hydraulic conductivity, $\mathrm{Ks}_{\text {stele }}$ ) and diameter of active vessels (vessel hydraulic conductivity, $\mathrm{Ks}_{\text {vessel }}$ ). Vessel functionality was measured using the slow dye perfusion method described by Tibbetts and Ewers (2000). These parameters were measured for both anchor and feeder roots and for all size classes.

Root samples $15 \mathrm{~cm}$ in length were obtained in the field and were immediately submerged in distilled water. In the laboratory, the external diameter of each root was measured with a digital caliper with an accuracy of $0.01 \mathrm{~mm}$. Thereafter, the maximum axial hydraulic conductivity $\left(\mathrm{Kh}_{\max }\right)$ was immediately measured, following the methodology used by Sperry et al. (1988) and North and Nobel (1994). Fragments $5 \mathrm{~cm}$ in length were taken from the central region of the submerged $15 \mathrm{~cm}$ root samples. Then, the tissues positioned externally to the stele were carefully removed from a $5 \mathrm{~mm}$ region of both tips. The proximal region of the segment was inserted into PVC tubing attached to an ultrapure water reservoir at room temperature, while the other end, also inserted into PVC tubing, was directed to a container on 
a digital scale with an accuracy of $0.01 \mathrm{~g}$. With the root samples submerged in distilled water, the fragments were pressurized with ultrapure water at $0.25 \mathrm{MPa}$ for ten minutes, always controlled by an Omega digital manometer with an accuracy of $0.0001 \mathrm{MPa}$, in order to unclog embolized vessels. Then the tips were trimmed, and the water was pressurized again to a maximum of $0.05 \mathrm{MPa}$ for the anchor roots and $0.02 \mathrm{MPa}$ for the feeder roots. The pressure applied to the anchor roots was higher owing to the morphoanatomical characteristics of the stele which is composed of narrower xylem vessels with high hydraulic resistance. The pressure applied on the roots was monitored through an Omega PX26 pressure microsensor. The amount of water carried by the root segments was measured every second for 15 minutes through a computer attached to the electronic scale. The maximum axial hydraulic conductivity $\left(\mathrm{Kh}_{\max }, \mathrm{kg}\right.$ $\mathrm{m} \mathrm{MPa}^{-1} \mathrm{~s}^{-1}$ ) was obtained as

$$
\operatorname{Khmax}=\frac{Q v}{\left(\frac{\Delta P}{l}\right)}
$$

where $\mathrm{Qv}\left(\mathrm{Kg} \mathrm{s}^{-1}\right)$ is the volumetric flow level, $\mathrm{P}$ is the pressure value (MPa) and $1(\mathrm{~m})$ is the sample length (North and Nobel, 1994). Qv was determined by the amount of water (kg) increase in time (s). The specific hydraulic conductivity $\left(\mathrm{Ks}, \mathrm{Kg} \mathrm{m} \mathrm{MPa}{ }^{-1} \mathrm{~s}^{-1} \mathrm{~m}^{-2}\right.$ ) was determined by the ratio of $\mathrm{Kh}$ to the active conductive area. To measure $\mathrm{Ks}_{\text {stele, }}$ the crosssectional area of the stele was used, while for $\mathrm{Ks}_{\text {vessel, }}$ the sum of the diameters of the active vessels identified in a cross section was used.

Digital photomicrographs of the samples used for Kh measurements were obtained using a Coolsnap digital camera coupled an Olympus BX-50 optical microscope. Measurements of stele diameter, as well as the number and diameter of the xylem vessels, were obtained using the Image-Pro Plus program (version 4.5.0.29). The area of stele and vessels $\left(\mathrm{m}^{2}\right)$ was calculated based on the assumption of both structures as circles. The total active conductive area was obtained by summing the areas of all active stele vessels.

\section{Statistical analyses}

Normal distribution of data was evaluated by the Kolmogorov-Smirnov (K-S) test, and homogeneity of variances was evaluated by Levene's test. After that, linear regressions were used to evaluate correlations between root and stele diameter and both xylem active area and root hydraulic conductivity in anchor and feeder roots. Differences among these relationships for anchor and feeder roots were detected by comparing their respective angular coefficients (i.e., scaling exponent $\alpha$ ) via Standardized Major Axis regression (SMATR; Warton et al., 2006) fitted to the allometric equation $\log \mathrm{Y}=\mathrm{a} \log \mathrm{X}+\log \mathrm{b}$, where a was the scaling exponent (slope) and $\mathrm{b}$ the scaling factor ( $\mathrm{Y}$ intercept; Niklas, 1994).

All anchor and feeder roots were compared to each other for the number of vessels by $t$-test, after validation of normality by the Shapiro-Wilk test. The frequency distributions of the diameter and number of vessels were compared for the anchor and feeder roots along the five plant size classes of $R$. oblongata. Eleven vessel diameter classes with increasing range of $5 \mu \mathrm{m}$ were determined for anchor $(0.0-5.0 ; 5.01-10.0 ; 10.1-15.0 ; 15.1-20.0 ; \ldots 50.1-55.0)$, while nine classes with increasing range of $20 \mu \mathrm{m}$ were defined for feeder roots $(0.0-20.0 ; 20.1-40.0 ; 40.1-60.0 ; 60.1-80.0$; ...160.1-180.0). Since the distribution pattern of the 'vessel diameter' parameter for both root types resembles a gamma probability distribution (data not shown), comparisons between size classes of $R$. oblongata for the same root type were made using the generalized linear model (GLM) with inverse binding function $\mu=(X \beta)^{-1}$ (Dobson and Barnett, 2008) where size class II ( 0 to $1 \mathrm{~m}$ in height) was taken as a reference. The same procedure was used to compare all anchor roots against all feeder roots regarding vessel diameters. The number of vessels per diameter class was also evaluated along the size classes of $R$. oblongata. Therefore, after validation of normality by the Shapiro-Wilk test, the GLM test was applied with identity function $\mu=\mathrm{X} \beta$ (Neter et al., 1996), again considering size class II ( 0 to $1 \mathrm{~m}$ in height) as reference. The $\mathrm{R}$ ( $\mathrm{R} x$ 64 3.4.1) platform was used for the above tests, with significance of $\mathrm{P} \leq 0.05$. 



Figure 1. Morphological aspects of Rhodospatha oblongata plants.

Habit of Rhodospatha oblongata. A. Individual of class II starts to climb a host surrounded by many terrestrial individuals of class I (sensu Filartiga et al., 2014). B. Individual of class VI positioned 7 meter in height on canopy. At the bottom of the same host individual of class II begins its ascension. C. Detail of B: note the large leaves (arrow) and several feeder roots (double arrow). D. Detail of aerial feeder (arrow) and aerial anchor roots (double arrow) arising from the stem of a class III individual. E. Transversal section of aerial feeder (AFR) and aerial anchor roots (AAR) from individuals of classes II, IV and VI. Note visible xylem vessel lumen from feeder roots of class IV and VI. Bar equals $2.5 \mathrm{~cm}$. 


\section{Results}

As individuals of $R$. oblongata ascend to the canopy and increase in size, their roots become thicker. This gradual external thickening is followed by the increase of stele area, as well as number and diameter of vessels. This increase occurs differently for anchor and feeder roots and greatly influences their respective hydraulic conductivities.

The anchor root varied only 3 times in external diameter against more than 7 times for feeder roots. The mean external diameter of the anchor roots is $1.83 \pm 0.76 \mathrm{~mm}$ versus $3.27 \pm 1.55 \mathrm{~mm}$ for the feeder root. The same pattern of greater variation occurred for the stele, which varied 2 times for the anchor roots and more than 4 times for the feeder roots. The highest values of external and stele diameters of both roots were found in the largest plants of $R$. oblongata (i.e., class VI), as established in the upper parts of the canopy (Table 1). Such increase in external and stele area was followed by an increase of respective hydraulic conductivity, always higher for larger roots inside each root type and for feeder roots when both types are compared. For example, for class VI, the feeder roots with the wider stele diameter showed a Kh value 122 times higher than that of anchor roots with wider stele diameter (Table 1). This variation likely occurred as a result of the increase in number and diameter of xylem vessels present in the stele of each root type, as evidenced by its anatomy and specific hydraulic conductivity.

Table 1. Minimum and maximum values of morphological and hydraulic conductivity data from aerial roots obtained along increasing size classes of Rhodospatha oblongata.

\begin{tabular}{|c|c|c|c|c|c|c|}
\hline \multirow{2}{*}{ Class } & \multicolumn{2}{|c|}{$\begin{array}{l}\text { External diameter } \\
\qquad\left(\mathrm{m}^{*} 10^{-3}\right)\end{array}$} & \multicolumn{2}{|c|}{$\begin{array}{l}\text { Stele diameter } \\
\qquad\left(\mathrm{m} * 10^{-3}\right)\end{array}$} & \multicolumn{2}{|c|}{$\begin{array}{c}\mathrm{Kh}_{\max } \\
\left(\mathrm{Kg} \mathrm{m} \mathrm{MPa}^{-1} \mathrm{~s}^{-1} * 10^{-6}\right)\end{array}$} \\
\hline & Anchor & Feeder & Anchor & Feeder & Anchor & Feeder \\
\hline \multirow{2}{*}{ II } & min: 0.99 & 0.88 & 0.36 & 0.53 & 0.053 & 0.849 \\
\hline & $\max : 1.40$ & 2.96 & 0.35 & 1.33 & 0.079 & 11.510 \\
\hline \multirow{2}{*}{ III } & min: 1.03 & 1.78 & 0.34 & 0.86 & 0.012 & 3.762 \\
\hline & $\max : 1.96$ & 3.41 & 0.77 & 1.97 & 0.278 & 22.093 \\
\hline \multirow{2}{*}{ IV } & $\min : 1.80$ & 1.81 & 0.69 & 1.03 & 0.197 & 5.515 \\
\hline & $\max : 2.56$ & 3.64 & 1.33 & 1.66 & 2.674 & 32.267 \\
\hline \multirow{2}{*}{ V } & min: 0.95 & 3.89 & 0.30 & 2.25 & 0.029 & 385.185 \\
\hline & $\max : 2.94$ & 5.12 & 1.36 & 2.39 & 1.372 & 488.692 \\
\hline \multirow{2}{*}{ VI } & min: 0.96 & 4.94 & 0.34 & 2.44 & 0.0162 & 278.923 \\
\hline & $\max : 3.67$ & 6.21 & 1.03 & 2.48 & 2.180 & 267.752 \\
\hline
\end{tabular}

Morphology and hydraulic conductivity of aerial roots from increasing five size classes of R. oblongata. Minimum and maximum values for external and stele diameters of the anchor feeder root roots of Rhodospatha oblongata; besides its respective maximum hydraulic conductivity $\left(\mathrm{Kh}_{\max }\right)$ are presented. Data of stele diameter and $\mathrm{Kh}$ were obtained from the same root samples analyzed for minimum and maximum values of external diameter $(\mathrm{n}=30)$. Class I (terrestrial crawling individuals lacking aerial roots, sensu Filartiga et al., 2014) is not shown.

The determination of specific hydraulic conductivity (Ks) was obtained by the transversal area of the stele $\left(\mathrm{Ks}_{\text {stele }}\right)$ (Table 2) and also by the sum of the transversal area of the active vessels ( $\mathrm{Ks}_{\text {vessel, }}$, Figure 2). The values of $\mathrm{Kh}$ and $\mathrm{Ks}_{\text {vessel }}$ are gradually higher as the external and stele diameter of each root becomes wider and the sum of the vessel area increases (Table 3). However, the scaling coefficient was always higher for feeder roots in comparison to anchor roots, which means that hydraulic conductivity increased faster for feeders, as long as they grew larger.

The aerial roots with the largest external diameter were found in classes V and VI, i.e., those at the top of the canopies, and these roots presented higher $\mathrm{Ks}$ values. The $\mathrm{Ks}_{\text {stele }}$ and $\mathrm{Ks}_{\text {vessel }}$ values were always higher for feeder roots which presented twice the sum of the conducting vessel area and number of active vessels when compared to anchor roots (Tables 2 and 3). The same pattern of higher values for feeder roots was also found for maximum vessel diameters.

Feeder roots presented more vessels $(t=4.07 ; \mathrm{df}=42.59, \mathrm{P}=0.001)$ than anchor roots (Table 2). Most xylem vessels of anchor roots had diameters from 5 to $20 \mu \mathrm{m}$, representing $77 \%$ of all vessels analyzed for the five size classes of $R$. oblongata. The largest xylem vessel in this root type was measured at $53.41 \mu \mathrm{m}$ in diameter, and the mean diameter of all anchor root vessels from all size classes of $R$. oblongata was measured at $15.2 \pm 9.04 \mu \mathrm{m}$. In the feeder roots, most vessel diameters varied between 20.1 to $60 \mu \mathrm{m}$, representing $57.5 \%$ of all active vessels, and the largest xylem vessel in this root type was measured at $172.9 \mu \mathrm{m}$. The distribution of number and diameters of xylem vessels varied between the two types of aerial roots, as well as among the increasing plant sizes of $R$. oblongata. 

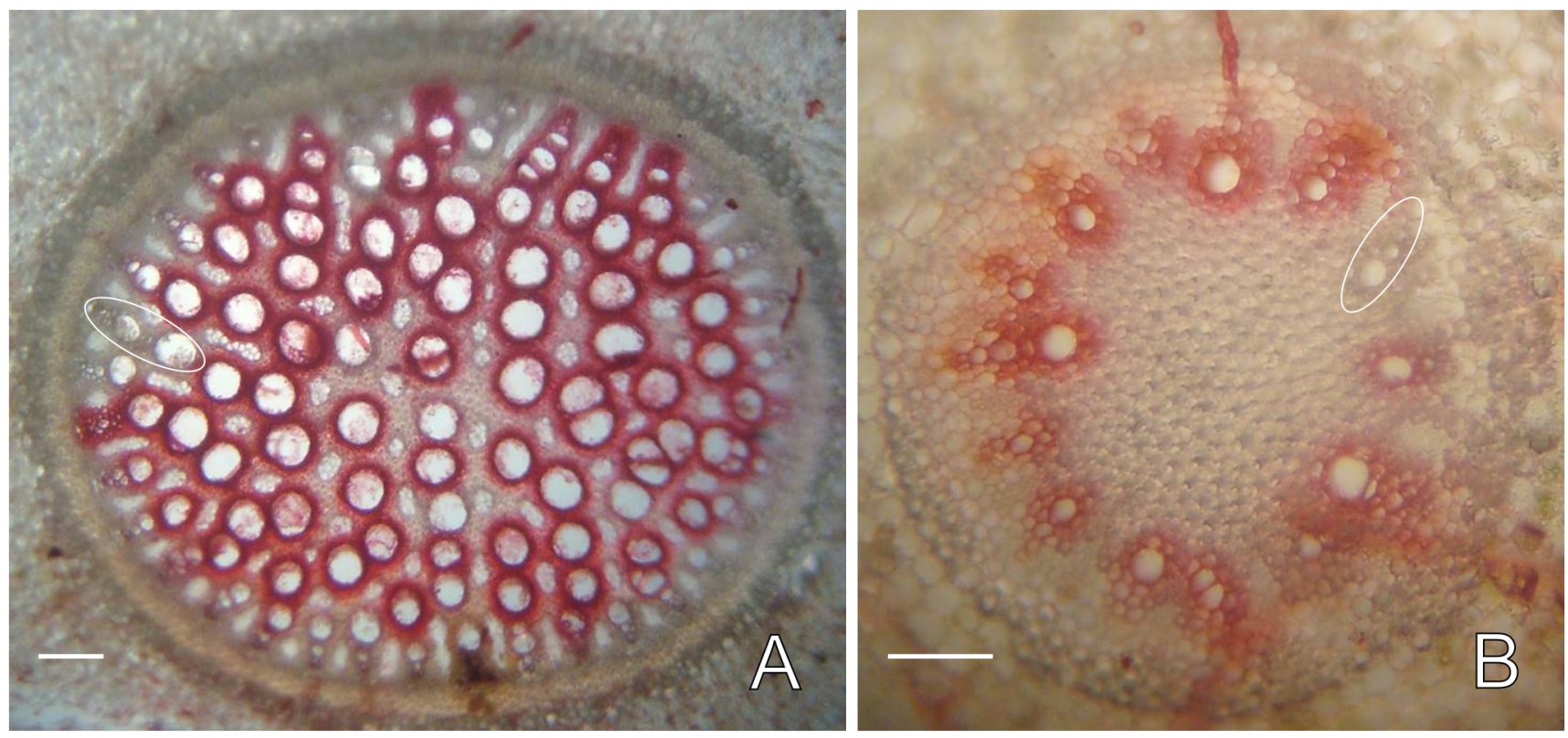

Figure 2. Xylem vessels of the aerial roots of Rhodospatha oblongata.

Active vessels detected by the dye perfusion technique. Cross sections of aerial feeder (A) and anchor root (B). The active xylem vessels are stained with Safranine and some of the inactive ones are delimited by an elipse. Bar $=100 \mu \mathrm{m}$.

Figure 3 shows the mean number of root xylem vessels per diameter class for the increasing sizes of $R$. oblongata. It should be noted that anchor and feeder roots are different in relation to vessel distribution pattern. While the mean number of vessels per diameter class has a monomodal distribution for anchor roots (Figure 3A), this distribution shows two peaks for the feeder roots (Figure 3B). For anchor roots, most vessels measure less than $20 \mu \mathrm{m}$ in diameter, independent of size class of $R$. oblongata. As noted, two peaks are clearly detected for feeder roots, and these peaks also vary with size class of $R$. oblongata. In smaller individuals (classes II to IV), these peaks occur respectively at 20 and $60-80 \mu \mathrm{m}$, while for the higher individuals (V and VI), they occur at 40 and $120 \mu \mathrm{m}$. Apparently, as $R$. oblongata grows, vessels also grow in number and size in the feeder roots. For example, vessels larger than $120 \mu \mathrm{m}$ in diameter are only found in classes V and VI.

This increase is confirmed when diameter and number of xylem vessels are compared by GLM analysis (Table 4). The diameter $(\mathrm{P}=0.001)$ and number of vessels $(\mathrm{P}=0.05)$ of anchor roots were significantly higher in classes IV to VI in comparison to classes II and III. However, for the anchor root, the vessels from class III are slightly larger and more numerous than vessels found in classes V and VI. In feeder roots, the diameter and number of vessels increased progressively from class IV to VI $(\mathrm{P}<0.01)$, and class III is not significantly different from class II for both parameters $(\mathrm{P}=0.09)$. Finally, considering all size classes of $R$. oblongata, feeder roots not only have larger vessels $(\mu$ $=56.49)$ than anchor roots $(\mu=15.24)$, but they are also more numerous $(\mathrm{W}=0.91 ; \mathrm{p}=0.02)$. 
Table 2. Minimum and maximum values of anatomical and specific hydraulic conductivity data from aerial roots obtained along increasing size classes of Rhodospatha oblongata.

\begin{tabular}{|c|c|c|c|c|c|c|c|c|c|c|c|c|c|}
\hline \multirow[t]{2}{*}{ Class } & & \multicolumn{2}{|c|}{$\begin{array}{l}\text { Stele transversal area } \\
\qquad\left(\mathrm{m}^{\left.2 * 10^{-7}\right)}\right.\end{array}$} & \multicolumn{2}{|c|}{ 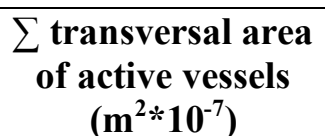 } & \multicolumn{2}{|c|}{$\begin{array}{c}\text { Number of } \\
\text { active vessels }\end{array}$} & \multicolumn{2}{|c|}{$\begin{array}{c}\text { Diameter of the } \\
\text { widest vessel }(\mu \mathrm{m})\end{array}$} & \multicolumn{2}{|c|}{$\begin{array}{c}\mathrm{Ks}_{\text {stele }} \\
\left(\mathrm{Kg} \mathrm{m} \mathrm{MPa}^{-1} \mathrm{~s}^{-1} \mathrm{~m}^{-2}\right)\end{array}$} & \multicolumn{2}{|c|}{$\begin{array}{c}\text { KSvessel } \\
\left(\mathrm{Kg} \mathrm{m} \mathrm{MPa}^{-1} \mathbf{s}^{-1} \mathbf{m}^{-2}\right)\end{array}$} \\
\hline & & Anchor & Feeder & Anchor & Feeder & Anchor & Feeder & Anchor & Feeder & Anchor & Feeder & Anchor & Feeder \\
\hline \multirow[t]{2}{*}{ II } & $\min$ & 0.66 & 1.96 & 0.61 & 0.17 & 49 & 26 & 29.86 & 46.54 & 0.78 & 5.41 & 8.40 & 60.19 \\
\hline & $\max$ & 2.20 & 13.88 & 0.46 & 1.82 & 67 & 100 & 11.29 & 93.07 & 0.22 & 8.28 & 10.80 & 63.14 \\
\hline \multirow[t]{2}{*}{ III } & $\min$ & 0.90 & 5.80 & 0.29 & 0.82 & 62 & 81 & 11.29 & 66.77 & 0.14 & 6.47 & 4.37 & 45.68 \\
\hline & $\max$ & 6.93 & 30.46 & 3.24 & 3.46 & 105 & 165 & 37.43 & 89.59 & 1.08 & 7.25 & 23.13 & 63.80 \\
\hline \multirow[t]{2}{*}{ IV } & $\min$ & 3.73 & 8.32 & 1.36 & 1.14 & 84 & 109 & 35.69 & 78.20 & 0.52 & 6.62 & 14.47 & 47.96 \\
\hline & $\max$ & 13.88 & 23.22 & 5.67 & 3.19 & 146 & 159 & 43.71 & 91.69 & 1.92 & 9.96 & 47.10 & 72.47 \\
\hline \multirow[t]{2}{*}{$\mathrm{V}$} & $\min$ & 0.70 & 25.15 & 0.45 & 9.26 & 50 & 236 & 19.55 & 129.67 & 0.41 & 163.10 & 6.51 & 442.93 \\
\hline & $\max$ & 14.51 & 44.83 & 6.58 & 6.33 & 128 & 205 & 43.71 & 108.26 & 0.94 & 108.98 & 20.82 & 771.35 \\
\hline VI & $\begin{array}{l}\min \\
\max \end{array}$ & $\begin{array}{c}0.90 \\
16.96\end{array}$ & $\begin{array}{l}46.73 \\
62.86\end{array}$ & $\begin{array}{l}0.43 \\
6.71\end{array}$ & $\begin{array}{l}13.03 \\
13.45\end{array}$ & $\begin{array}{c}36 \\
178\end{array}$ & $\begin{array}{l}229 \\
281\end{array}$ & $\begin{array}{l}27.65 \\
52.94\end{array}$ & $\begin{array}{l}165.11 \\
151.43\end{array}$ & $\begin{array}{l}0.17 \\
1.67\end{array}$ & $\begin{array}{c}59.68 \\
156.19\end{array}$ & $\begin{array}{c}3.72 \\
42.65\end{array}$ & $\begin{array}{l}213.89 \\
730.11\end{array}$ \\
\hline
\end{tabular}

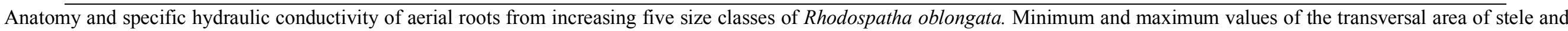

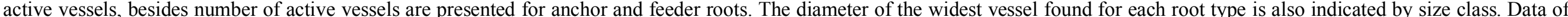

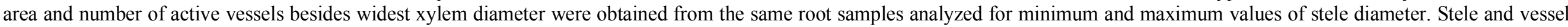

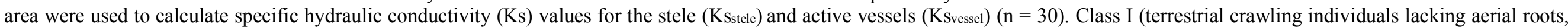
sensu Filartiga et al., 2014) is not shown. 
Journal of Plant Hydraulics 4: e-006

Table 3. Relationship between morphological, anatomical and hydraulic conductivity parameters from aerial roots of Rhodospatha oblongata.

\begin{tabular}{|c|c|c|c|c|c|c|c|}
\hline \multicolumn{2}{|c|}{ Parameters } & \multirow{2}{*}{ Anchor } & \multirow{2}{*}{ Feeder } & \multicolumn{2}{|c|}{ Anchor } & \multicolumn{2}{|c|}{ Feeder } \\
\hline & & & & $\alpha$ & IC & $\alpha$ & IC \\
\hline $\begin{array}{l}\text { External } \\
\text { transversal area }\end{array}$ & $\begin{array}{l}\text { Stele transversal } \\
\text { area }\end{array}$ & $0.96^{*}$ & $0.90 *$ & $1.34 \pm 0.08^{\mathrm{NS}}$ & 1.19 to 1.52 & $0.95 \pm 0.03^{\mathrm{NS}}$ & 0.88 to 1.03 \\
\hline $\begin{array}{l}\text { Stele transversal } \\
\text { area }\end{array}$ & $\mathrm{Kh}$ & $0.90 *$ & $0.86^{*}$ & $1.75 \pm 0.12 *$ & 1.51 to 2.0 & $2.59 \pm 0.14$ & 2.30 to 2.91 \\
\hline
\end{tabular}

Summary of linear regressions between morphological, anatomical and hydraulic conductivity parameters of aerial anchor and feeder roots of Rhodospatha oblongata. $(\mathrm{n}=30)$. Regression coefficients are derived from logarithmic allometric models. Symbols $(*)$ indicate significant regressions $(\mathrm{P}<0.001)$ and also significant differences when scaling coefficient values from anchor and feeder roots are compared. (* $\mathrm{P}<0.001 ; * * \mathrm{P}<0.002$; NS - non significant).

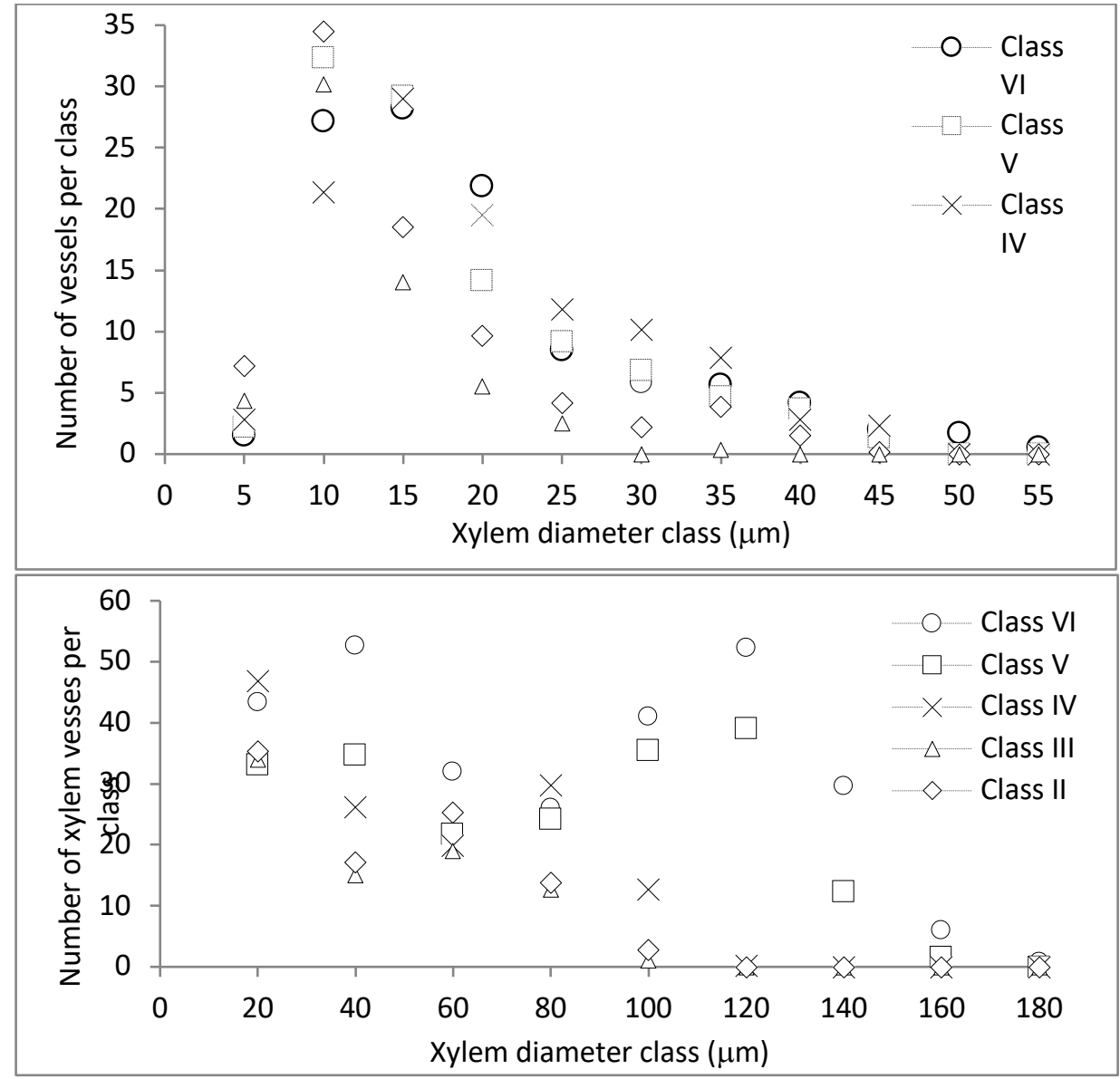

Figure 3. Number of xylem vessels in the aerial roots of Rhodospatha oblongata.

Number of xylem vessels per diameter class of aerial roots from increasing five size classes of Rhodospatha oblongata. A. Anchor roots present an unimodal distribution showing that most vessels have small diameters (5 to $20 \mu \mathrm{m})$. $\mathrm{n}=2749$. B. Feeder roots present a bimodal distribution showing that most vessels are concentrated on smaller (20.1 to $40 \mu \mathrm{m})$ and larger $(>60.1 \mu \mathrm{m})$ diameters along all size classes. Vessels larger than $120 \mu \mathrm{m}$ occur only at size classes V and VI. Data are mean. $\mathrm{n}=4580$. 
Table 4. Generalized linear model test comparing diameter and number of xylem vessels along increasing size classes of Rhodospatha oblongata.

\begin{tabular}{ccccc}
\hline \multirow{2}{*}{ Class } & \multicolumn{2}{c}{ Anchor root } & \multicolumn{2}{c}{ Feeder root } \\
& Vessel diameter & Vessel number & Vessel diameter & Vessel number \\
\hline II & $10.24^{1}$ & $56.83^{1}$ & $26.54^{1}$ & $81.67^{1}$ \\
III & $12.82^{* * * 2}$ & $83.16^{1}$ & $27.95^{\text {ns1 }}$ & $94.50^{\text {ns1 }}$ \\
IV & $17.43^{* * * 5}$ & $107.66^{* 4}$ & $31.18^{* * * 2}$ & $135.50^{* * 2}$ \\
V & $15.62^{* * * 3}$ & $103.5^{* 2}$ & $44.69^{* * * 3}$ & $202.00^{* * * 3}$ \\
VI & $17.15^{* * * 4}$ & $107^{* 3}$ & $46.10^{* * * 4}$ & $283.84^{* * * 4}$ \\
\hline
\end{tabular}

Comparison among increasing size classes of Rhodospatha oblongata based on diameter and number of xylem vessels. Both parameters are compared for aerial anchor and feeder roots. Data are $\mu$ statistics based on inverse binding (for vessel diameter) and identity (for number of vessels) calculated by generalized linear model (GLM). Asterisks compare diameter or number of vessels per root type, considering size class II as reference: * $(<0.05)$; ** $(<0.01)$; *** $(<0.001)$. Non-significant difference is identified by NS. Superscript numbers identify the crescent order of diameter or of number of vessels along size classes.

\section{Discussion}

The adventitious root system of $R$. oblongata increases in size (length and external diameter) as long as this plant species ascends the host toward the canopy (Filartiga et al., 2014). Data presented herein show that this increment is followed by an increase in number and diameter of xylem vessels, improving the respective axial hydraulic conductivity of anchor and feeder roots with plant size. These data agree with recent findings that relate increasing organ axis diameter to the increase of xylem vessel diameter among angiosperms (Olson et al., 2014; Rosell et al., 2017). It is noteworthy that stem and respective xylem vessels from aroid vines taper acropetally, while trees taper basipetally (Lopez-Portillo et al., 2000). Also, while aerial roots from aroid vines do not taper, their respective stems do (Filartiga et al., 2014). It is functionally expected that the diameter of xylem vessels will increasein diameter since they connect large canopy leaves to soil water. However, the same is not functionally expected of anchor roots since their main function involves adherence of the aroid vine to the host (Croat, 1988).

Both aerial roots of $R$. oblongata are initially differentiated by their dimensions. Anchor roots are short and thin, and feeder roots are long and thick (Hinchee, 1981; Croat, 1988). Such morphological variation would indicate potential functional difference. That is, while anchor roots are responsible for securing vine to host with no connection to the soil, feeder roots are responsible for transporting water and nutrients from the soil to the canopy. Anatomical comparison between the steles of both roots reinforces these different functional roles. Specifically, in anchor roots, the number and diameter of xylem vessels are respectively two and four times smaller compared to feeder roots. In addition, anchor roots have clear lignified pith without vessels, while feeder roots present large vessels occupying almost the entire stele (Filartiga et al., 2014).

The xylem vessels of $R$. oblongata feeder roots were similar in diameter to those recorded to feeder roots of Monstera acuminata C. Koch, the only lianescent Araceae whose hydraulic architecture has been studied, although this species can present vessels reaching $250 \mu \mathrm{m}$ in diameter (López-Portillo et al., 2000). These wide R. oblongata vessels are similar to those found in stems of lianas, often characterized by vessels with high diameters, ranging from 150 to $380 \mu \mathrm{m}$, and correspondingly high hydraulic conductivity values (Ewers and Fisher, 1989; Ewers et al., 1989; Ewers et al., 1990; Gartner et al., 1990; Ewers and Fisher, 1991; Tibbetts and Ewers, 2000). In fact, the Ks stele in liana stems reaches high values, up to $110 \mathrm{Kg} \mathrm{m} \mathrm{MPa}^{-1} \mathrm{~s}^{-1} \mathrm{~m}^{-2}$ (Gartner et al., 1990; Tibbetts and Ewers, 2000). The maximum values of xylem diameter and $\mathrm{Ks}_{\text {stele }}$ measured for $R$. oblongata feeder roots were respectively $170 \mu \mathrm{m}$ and $160 \mathrm{Kg} \mathrm{m} \mathrm{MPa}{ }^{-1} \mathrm{~s}^{-1} \mathrm{~m}^{-2}$, equating the Araceae to lianas with respect to xylem hydraulic efficiency.

Wide vessels are potentially more susceptible to cavitation and embolism in comparison to narrow vessels (Zimmermann, 1983). The fact that a bimodal distribution of vessel diameters is only present at feeder roots and not anchor roots resembles the same pattern as that found when comparing ring porous to diffusive porous trees (Sperry et al., 1994). In this analogy, 'ring porous structure' has higher Kh, but is more susceptible to embolism than 'diffusive porous' structure, mainly by the presence of many large vessels (Sperry et al., 1987). The opposite trend could be hypothesized whereby the presence of small vessels in feeder roots could help maintain xylem activity when embolism stops the transport activity of large vessels. In fact, small tracheary elements, sometimes less than $10 \mu \mathrm{m}$ in diameter, are found on the xylem of $R$. oblongata aerial roots. These elements could be tracheids or vessels, the differentiation of which could be better defined by the presence of porous pit membranes at the perforation plate (Schneider and Carlquist, 1998), as detected via scanning electron microscopy (see Carlquist, 2012 for review). Herein it has been demonstrated that water is conducted by these small tracheary elements. Even so, the presence of mechanisms to avoid, or dissolve, embolisms in large xylem vessels of the feeder roots of $R$. oblongata would be expected.

Positive root pressure typically dissolves embolisms and reactivates vessels (Zimmermann, 1983; Tibbetts and Ewers, 2000). López-Portillo et al. (2000) detected root pressure on the order of $200 \mathrm{kPa}$ for the aroid vine Monstera 
acuminata. Among dicotyledonous lianas, root pressure is relatively rare, reaching up to $64 \mathrm{kPa}$ in only 3 of the 29 surveyed species by Cochard et al. (1994) and up to $145 \mathrm{kPa}$ in Vitis riparia Michaux studied by Tibbetts and Ewers (2000). In $R$. oblongata, values of $50 \mathrm{kPa}$ have already been detected at $1.5 \mathrm{~m}$ in height (A. Mantovani, persn. commun.) during the wet season. This pressure could push water, in theory, 5 meters in height against gravity (Ewers et al., 1997), suggesting that the hydraulic conductivity of large feeder root vessels could, therefore, be repaired.

The values of $\mathrm{Ks}_{\text {stele }}$ obtained for anchor roots of $R$. oblongata are smaller than those detected for feeder roots, which reveals lower functionality of the former for water transport. The hydraulic conductivity was not evaluated for anchor roots of M. acuminata, owing to its small size (López-Portillo et al., 2000), which is common to the genus (Hinchee, 1981). The fact that the xylem vessels increase in diameter in the thicker anchor roots of $R$. oblongata reveals a potential increase of their hydraulic conductivity. Indeed, the thicker anchor roots presented more and larger vessels than the thinner anchor roots, resulting in greater $\mathrm{Ks}_{\text {stele. }}$. This result appears to call into question their role of mere fixation to the host (Vianna et al., 2001). The absorption of water and nutrients that slide through the host's trunk would represent a complementary way of obtaining resources (Benzing, 1990) for aroid vines rooted in the forest floor (Zotz, 2013). For R. oblongata, it is important to note that both root types feature trichomes that directly adhere to the host (Mantovani et al., 2017), that anchor roots are more frequent per individual plant than feeder roots (e.g., mean of 94 anchor against 10 feeder roots per individual from size class VI) (Filartiga et al., 2014), and that the horizontal water transport of anchor roots is not constrained by gravity as it is in vertical feeder roots (McCulloh and Sperry, 2005). However, the capacity of anchor roots of aroid vines to absorb and transport water has never been tested.

Allometric modifications in the shape and hydraulic architecture of the vegetative body can optimize light, carbon and water flux in plants, minimizing constraints imposed by vertical growth. For aroid vines, the few studies done with light foraging indicate that large leaves at canopies have higher photosynthetic capacity (measured via chlorophyll fluorescence) than leaves positioned near the soil (Filartiga et al., 2014; Mantovani et al., 2017), and it is known that this is dependent on correspondingly high water flux (McCulloh and Sperry, 2005). While allomorphic changes are commonly reported for shoots and leaves of aroid vines (López-Portillo et al., 1990; Mantovani et al., 2017), the results herein reported show that functional allomorphy could also be extended to the aerial roots, both anchor roots, when they exist, and feeder roots. Such morphological changes can improve water transport efficiency and help maintenance of aroid vines in canopy.

\section{Acknowledgements}

AM thanks Drs. Karen De Toni, Claudia Franca Barros, Neusa Tamaio and Helena Regina Pinto Lima for discussion about small tracheary elements. AM is grateful to Fundacão de Amparo a Pesquisa do Estado do Rio de Janeiro (FAPERJ - Process number 210.722/2016) for funding the aroid project. The authors thank the reviewer Dr. Frederic Lens and the Editor Dr. Sylvain Delzon whose comments and suggestions helped improve and clarify this manuscript.

\section{References}

Benzing DH. 1990. Vascular epiphytes. General biology and related biota. Cambridge University Press, Cambridge doi: $10.1017 / \mathrm{S} 0266467400006088$

Carlquist S. 2012. Monocot xylem revisited: new information, new paradigms. Botanical Review 78: 87-153 doi: 10.1007/s12229-012-9096-1

Cochard H, Ewers FW, Tyree MT. 1994. Water relations of a tropical vine-like bamboo (Rhipidocladum racemiflorum): root pressures, vulnerability to cavitation and seasonal changes in embolism. Journal of Experimental Botany 45: 1085-1089 doi: 10.1093/jxb/45.8.1085

Croat TB. 1988. Ecology and life forms. Aroideana 11: 4-55

Dobson AJ, Barnett AG. 2008. An Introduction to Generalized Linear Models, 3rd Ed. Chapman \& Hall/CRC, Boca Raton

Ewers FW, Cochard H, Tyree MT. 1997. A survey of root pressures in vines of a tropical lowland forest. Oecologia 110: 191-196 doi: 10.1007/s004420050149

Ewers FW, Fisher JB. 1989. Variation in vessel length and diameter in stems of six tropical and subtropical lianas. American Journal of Botany 76: 1452-1459 doi: 10.1002/j.1537-2197.1989.tb15126.x

Ewers FW, Fisher JB. 1991. Why vines have narrow stems: histological trends in Bauhinia. Oecologia 88: 233-237 doi: 10.1007/BF00320816

Ewers FW, Fisher JB, Chiu ST. 1989. Water transport in the liana Bauhinia fassoglensis (Fabaceae). Plant Physiology 91: 1625-1631 doi: 10.1104/pp.91.4.1625

Ewers FW, Fisher JB, Chiu ST. 1990. A survey of vessel dimensions in stems of tropical lianas and other growth forms. Oecologia 84: 544-552 doi: 10.1007/BF00328172. 
Filartiga AL, Vieira RC, Mantovani A. 2014. Size-correlated morpho-physiology of the aroid vine Rhodospatha oblongata along a vertical gradient in a Brazilian rain forest. Plant Biology 16: 155-165 doi: 10.1111/plb.12023

Gartner BL, Bullock SH, Mooney HA, Brown B, Whitbeck JL. 1990. Water transport properties of vine and tree stems in a tropical deciduous forest. American Journal of Botany 77: 742-749 doi: 10.2307/2444366

Hinchee MAW. 1981. Morphogenesis of aerial and subterranean roots of Monstera deliciosa. Botanical Gazette 142: 347-359 doi: 10.1086/337234

Lopez-Portillo J, Ewers FW, Angeles G, Fisher JB. 2000. Hydraulic architecture of Monstera acuminata: evolutionary consequences of the hemiepiphytic growth form. New Phytologist 145: 289-299 doi: 10.1046/j.14698137.2000.00578.x

Mantovani A. 1999b. Leaf morpho-physiology and distribution of epiphytic aroids along a vertical gradient in a brazilian rain forest. Selbyana 20: 241-249

Mantovani A, Pereira, TE, Mantuano D. 2017. Allomorphic growth of Epipremnum aureum (Araceae) as characterized by changes in leaf morphophysiology during the transition from ground to canopy. Brazilian Journal of Botany 40: 177-191 doi: 10.1007/s40415-016-0331-6

McCulloh KA, Sperry JS. 2005. Patterns in hydraulic architecture and their implications for transport efficiency. Tree Physiology 25: 257-267 PMID: 15631974

Neter J, Kutner MH, Nachtsheim CJ, Wasserman W. 1996. Applied linear statistical models. Irwin, Chicago

Niklas KJ. 1994. Plant allometry: The scaling of form and process. University of Chicago Press, Chicago

North GB, Nobel PS. 1994. Changes in root hydraulic conductivity for two tropical epiphytic cacti as soil moisture varies. American Journal of Botany 81: 46-53 doi: 10.1002/j.1537-2197.1994.tb15407.x

Olson ME, Anfodillo T, Rosell JA, Petit G, Crivellaro A, Isnard S, León-Gómez C, Alvarado-Cárdenas LO, Castorena M. 2014. Universal hydraulics of the flowering plants: vessel diameter scales with stem length across angiosperm lineages, habits and climates. Ecology Letters 17: 988-997 doi: 10.1111/ele.12302

Ray TS. 1990. Metamorphosis in the Araceae. American Journal of Botany 77: 1599-1609 doi: 10.2307/2444492

Ray TS. 1992. Foraging behavior in tropical herbaceous climbers (Araceae). Journal of Ecology 80: 89-203 doi: $10.2307 / 2261006$

Rosell, JA, Olson, ME, Anfodillo, T. 2017. Scaling of xylem vessel diameter with plant size: causes, predictions, and outstanding questions. Current Forestry Reports 3: 46-59 doi: 10.1007/s40725-017-0049-0

Schneider EL, Carlquist, S. 1998. Origin and nature of vessels in monocotyledons. 4. Araceae subfamily Philodendroideae. Journal of Torrey Botanical Society 125: 253-260 doi: 10.2307/2997239

Sperry JS, Donnelly JR, Tyree MT. 1988. A method for measuring hydraulic conductivity and embolism in xylem. Plant Cell and Environment 11: 35-40 doi: 10.1111/j.1365-3040.1988.tb01774.x

Sperry JS, Holbrook NM, Zimmermann MH, Tyree MT. 1987. Spring filling of xylem vessels in wild grapevine. Plant Physiology 83: 414-417 PMID: 16665259

Sperry JS, Nichols KL, Sullivan JEM, Eastlack SE. 1994. Xylem embolism in ring-porous, diffuse-porous and coniferous trees of northern Utah and interior Alaska. Ecology 75: 1736-1752 doi: 10.2307/1939633

Tibbetts TJ, Ewers FW. 2000. Root pressure and specific conductivity in temperate lianas: exotic Celastrus orbiculatus (Celastraceae) vs. native Vitis riparia (Vitaceae). American Journal of Botany 87: 1272-1278 PMID: 10991898

Warton DI, Wright IJ, Falster DS, Westoby M. 2006. Bivariate line-fitting methods for allometry. Biological reviews of the Cambridge Philosophical Society 81: 259-291 doi: 10.1017/S1464793106007007

Vianna OW, Soares MKM, Appezatto-da-Gloria B. 2001. Anatomia da raiz escora de Philodendron bipinnatifidum Schott (Araceae). Acta Botanica Brasilica 15: 313-320 doi: 10.1590/S0102-33062001000300003

Zimmermann MH. 1983. Xylem structure and the ascent of sap. Springer, Berlin doi: 10.1007/978-3-662-04931-0

Zimmermann MH, Potter D. 1982. Vessel-length distribution in branches, stem and roots of Acer rubrum L. IAWA Bulletin new series 3: 103-109 doi: 10.1163/22941932-90000759

Zotz G. 2013. Hemiepiphyte: a confusing term and its history. Annals of Botany 111: 1015-1020 doi:10.1093/aob/mct085 